\title{
Karnoprawne i kryminologiczne aspekty przestępstwa plagiatu
}

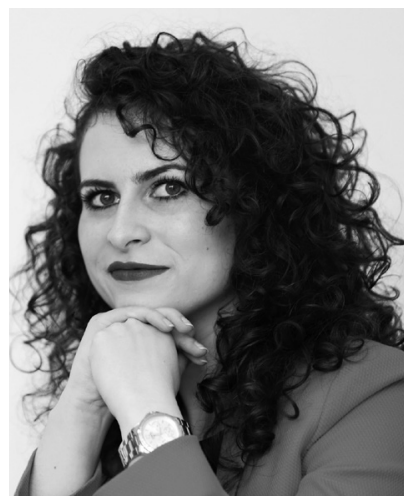

\footnotetext{
Natalia Daśko

Doktor nauk prawnych, adiunkt w Katedrze Prawa Karnego na Wydziale Prawa i Administracji Uniwersytetu Mikołaja Kopernika. Zajmuje się prawem karnym, karnoprawną ochrona własności intelektualnej oraz zagadnieniami związanymi zochrona danych osobowych.

ndasko@umk.pl

https://orcid.org/o00o-0001-9122-4883
}

\section{Criminal Law and Criminological Aspects of the Plagiarism}

\begin{abstract}
The article consists of two parts. In the first, the author discusses the criminal law aspects of the crime under Art. 115 paragraph 1 of the Act on Copyright and Related Rights. The second part presents the results of empirical research. In order to learn the dynamics of convictions over the years, characteristics of perpetrators and types of punishments imposed by courts, the author collected and developed statistical data obtained from the Ministry of Justice. In order to examine the factual circumstances of plagiarism cases, as well as the correctness of the legal classification of offenses used by the courts, the author conducted a case study. The research covered cases ended with a final conviction in 2013-2017. The summary includes comments regarding problems with the legal classification of infringements of copyright and related rights as well as de lege ferenda postulates.
\end{abstract}

Słowa kluczowe: prawo autorskie, prawo karne, kryminologia, plagiat, naruszenie praw autorskich

Key words: copyright, criminal law, criminology, plagiarism, copyright infringement

https://doi.org/10.32082/fp.v0i3(59).360

Przywłaszczenie cudzego autorstwa było kryminalizowane już na gruncie pierwszej polskiej ustawy o prawie autorskim z 29 marca 1926 r. ${ }^{1}$ i systematycznie utrzymywane w kolejnych aktach prawnych regulujących tę materię. Obecnie obowiązująca ustawa z 4 lutego

1 Ustawa z 29 marca 1926 r. o prawie autorskim, Dz.U. nr 48, poz. 286.
1994 r. $^{2}$ również przewiduje w art. 115 ust. 1 odpowiedzialność karną za naruszenie prawa do autorstwa, występującą obok odpowiedzialności cywilnej, która powinna odgrywać zasadniczą rolę w płaszczyźnie naruszenia autorstwa.

2 Ustawa z 4 lutego 1994 r. o prawie autorskim i prawach pokrewnych, t.j. Dz.U. 2019, poz. 1231 ze zm. (dalej: pr. aut.). 
Plagiat, prawdopodobnie najbardziej rozpoznawalne przestępstwo przeciwko prawom autorskim i prawom pokrewnym, nie pojawia się zbyt często w praktyce wymiaru sprawiedliwości. Tym bardziej interesujące było poznanie, jakiego rodzaju przypadki naruszenia prawa do autorstwa kończą się wyrokiem skazującym, kim są sprawcy tych przestępstw oraz czy można wyodrębnić, a jeśli tak to jakie, cechy charakterystyczne spraw plagiatowych. Ważne było także zbadanie, jak sądy radzą sobie z kwalifikacją prawną naruszeń praw autorskich i praw pokrewnych, gdyż wśród praktyków prawa panuje dość powszechny pogląd, że zagadnienia własności intelektualnej sprawiają sądom, zwłaszcza sądom karnym, trudności ${ }^{3}$. Ta stosunkowo niewielka liczba skazań $\mathrm{z}$ art. 115 ust. 1 pr. aut. pozwoliła na przeprowadzanie gruntownych

\section{Karnoprawne aspekty plagiatu}

Artykuł 115 pr. aut. penalizuje trzy typy przestępstw przeciwko prawom autorskim i prawom pokrewnym: przywłaszczenie autorstwa albo wprowadzenie w błąd co do autorstwa całości lub części cudzego utworu albo artystycznego wykonania (ust. 1); rozpowszechnianie bez podania nazwiska lub pseudonimu twórcy cudzego utworu (artystycznego wykonania) w wersji oryginalnej albo w postaci opracowania, albo publiczne zniekształcanie cudzego utworu w wersji oryginalnej albo w postaci opracowania, artystycznego wykonania, fonogramu, wideogramu lub nadania (ust. 2); naruszenie wymienionych enumeratywnie cudzych praw autorskich lub praw pokrewnych w inny sposób niż opisany w dwóch poprzedzających ustępach tego artykułu albo niewykonywanie określonych, enume-

\section{Plagiat, prawdopodobnie najbardziej rozpoznawalne} przestępstwo przeciwko prawom autorskim i prawom pokrewnym, nie pojawia się zbyt często $\mathrm{w}$ praktyce wymiaru sprawiedliwości.

badań empirycznych. W celu poznania dynamiki skazań na przestrzeni lat, charakterystyki sprawców oraz rodzajów kar wymierzanych przez sądy zebrano i opracowano dane statystyczne uzyskane z Ministerstwa Sprawiedliwości. Natomiast w celu zbadania okoliczności faktycznych spraw plagiatowych, a także poprawności kwalifikacji prawnej czynów zabronionych stosowanej przez sądy przeprowadzono badania aktowe. Badania obejmowały sprawy zakończone prawomocnym wyrokiem skazującym w latach 2013-2017.

3 A. Sokołowska-Ławniczak, P. Podrecki, Sprawy z zakresu własności intelektualnej czekaja na swój sąd, „Rzeczpospolita”, https://www.rp.pl/Firma/310209984-Sprawy-z-zakresu-wlasnosci-intelektualnej-czekaja-na-swoj-sad. html (dostęp 16.04.2020). ratywnie wymienionych obowiązków (ust. 3).

Konstrukcja tego przepisu budzi zastrzeżenia, ponieważ umieszczono w nim czyny zabronione godzące w różne dobra prawne oraz o różnej społecznej szkodliwości. Czyny stypizowane w art. 115 ust. 1 i 2 pr. aut. naruszają prawa osobiste, zaś czyn z art. 115 ust. 3 pr. aut. także prawa majątkowe. Można mieć również wątpliwości co do konieczności kryminalizacji niektórych z tych czynów, zwłaszcza mając na uwadze subsydiarność prawa karnego i zasadę ultima ratio.

Głównym przedmiotem ochrony w przypadku art. 115 ust. 1 pr. aut. jest podstawowe prawo osobiste twórcy, tj. prawo do autorstwa utworu oraz odpowiadające mu paralelne prawo artysty wykonawcy. Zapewnia ono autorowi (artyście wykonawcy) ochronę przed przypisywaniem sobie autorstwa przez nieuprawnionego i możliwość decydowania, czy i w jaki sposób oznaczyć autorstwo dzieła (wykonawstwa). Jako 
dodatkowy przedmiot ochrony, istotny z perspektywy osób trzecich - odbiorców utworów i artystycznych wykonań - wskazuje się prawo do informacji o rzeczywistym autorze utworu lub artystycznego wykonania ${ }^{4}$.

Przywłaszczenie autorstwa polega na podjęciu działań, w wyniku których sprawca traktuje cudzy utwór (artystyczne wykonanie) jak swój własny ${ }^{5}$. Może zostać dokonane w dowolny sposób, byle tylko zachowanie sprawcy wyraźnie wskazywało, że traktuje on cudzy utwór (artystyczne wykonanie) jak pochodzący od niego. Znamiona czynu zabronionego określonego w art. 115 ust. 1 pr. aut. zostaną zrealizowane w momencie, gdy sprawca uzewnętrzni fakt, że traktuje cudzy utwór (artystyczne wykonanie) jak pochodzący od siebie, co nie musi się wiązać z rozpowszechnieniem przejętego dzieła czy działaniem publicznym. Dla realizacji znamion przestępstwa plagiatu nie ma też znaczenia, czy osoby trzecie zostaną wprowadzone w błąd co do autorstwa, czy też zabiegi sprawcy będą na tyle nieudolne, że plagiat będzie natychmiast rozpoznawalny ${ }^{6}$.

Wyróżnia się plagiat całościowy, tj. obejmujący cały utwór lub artystyczne wykonanie, i częściowy, który dotyczy jedynie ich części. Tradycyjnie plagiat dzieli się także na jawny i ukryty. Ten pierwszy to przejęcie cudzego utworu lub artystycznego wykonania wprost (w niezmienionej postaci) lub tylko z minimalnymi modyfikacjami, jak np. zmiana koloru, przestawienie szyku zdań, usunięcie pewnych fragmentów itp. Natomiast plagiat ukryty wymaga większej inwencji twórczej plagiatora i zakłada pogłębioną modyfikację przejętego utworu, tak aby zakamuflować przejęcie i upozorować własne autorstwo. Ten rodzaj plagiatu

4 N. Daśko (w:) A. Michalak (red.), Ustawa o prawie autorskim i prawach pokrewnych. Komentarz, Warszawa 2019, s. 757; J. Zagrodnik (w:) P. Ślęzak (red.), Ustawa o prawie autorskim i prawach pokrewnych. Komentarz, Warszawa 2017, s. 815; por. także wyrok SN z 31 lutego 1935 r., sygn. akt I K 739/34, OSN(K) nr 9/1935, poz. 373.

5 K. Gienas (w:) E. Ferenc-Szydełko, Ustawa o prawie autorskim i prawach pokrewnych. Komentarz, Warszawa 2016, art. 115, nb. 3, Legalis.

6 N. Daśko (w:) A. Michalak (red.), Ustawa o prawie..., s. 758, 760; J. Raglewski (w:) D. Flisak (red.), Prawo autorskie i prawa pokrewne. Komentarz, Warszawa 2014, s. 1415. jest zdecydowanie trudniejszy do wykrycia ${ }^{7}$. Plagiat spełniający przesłanki dzieła zależnego jest chroniony przez prawo autorskie w sytuacji, gdy plagiator przywłaszczający elementy twórcze cudzego utworu (artystycznego wykonania) wnosi jednocześnie wkład twórczy w rozumieniu prawa autorskiego do powstałego w ten sposób dzieła ${ }^{8}$. Można zatem wyobrazić sobie taki przypadek, że sprawca przywłaszczający sobie autorstwo utworu (artystycznego wykonania) będącego $\mathrm{w}$ części plagiatem sam również poniesie odpowiedzialność karną za plagiat.

O plagiacie można mówić jedynie wówczas, gdy dochodzi do przejęcia twórczych elementów utworu (artystycznego wykonania). Oznacza to, że dzieło twórcy nie jest zazwyczaj chronione w całości, a jedynie w tych elementach, które spełniają prawnoautorskie przesłanki utworu, elementy nietwórcze, tj. banalne, nieoryginalne, mogą być przejmowane przez inne osoby ${ }^{9}$.

Ochroną prawnoautorską, także karnoprawną, nie są objęte odkrycia, idee, procedury, metody i zasady działania oraz koncepcje matematyczne (art. 1 ust. $2^{1}$ pr. aut.). Wobec tego, gdy ktoś przedstawia jako własne cudze ustalenia naukowe, teorie, odkrycia, pomysły, wyniki eksperymentów itp., to nie wypełnia znamion przestępstwa $z$ art. 115 ust. 1 pr. aut. Natomiast będzie ponosić odpowiedzialność karną $\mathrm{w}$ wypadku skopiowania sposobu wyrażenia powyższych, np. w publikacji naukowej, prezentacji itd., ponieważ w świetle art. 1 ust. $2^{1}$ pr. aut. przedmiotem ochrony objęty jest sposób ich wyrażenia, a zatem choć sama idea nie jest chroniona, chroniona jest jej forma ${ }^{10}$.

Rozmiar przejmowanych elementów twórczych z cudzego dzieła nie ma znaczenia dla kwalifikacji prawnej czynu jako plagiat. Plagiatem może być przywłaszczenie nawet bardzo krótkich części cudzego

7 N. Daśko (w:) A. Michalak (red.), Ustawa o prawie..., s. 758; H. Popławski, Przestępstwa naruszające prawo autorskie, Problemy Praworządności 1983, nr 11, s. 14.

8 R. Markiewicz, Zabawy z prawem autorskim, Warszawa 2015, s. 89.

9 N. Daśko (w:) A. Michalak (red.), Ustawa o prawie..., s. 758

10 J. Barta, R. Markiewicz, Prawo autorskie, Warszawa 2017, s. 32; K. Gienas (w:) E. Ferenc-Szydełko, Ustawa o prawie..., art. 115 , nb. 6 , Legalis. 
utworu (artystycznego wykonania), tj. pojedynczych zdań, kilku dźwięków, o ile spełniają one przesłanki prawnoautorskiej ochrony. Jednakże rozmiar przejmowanych elementów twórczych może mieć wypływ na wymiar kary, przy czym trzeba zaznaczyć, że gdy sprawca przejmuje niewielki nawet fragment cudzego utworu, ale czyni z niego istotny punkt swojej pracy (np. przywłaszczenie rozpoznawalnego motywu w utworze muzycznym) nie można uznać, że niewielki rozmiar przejętego dzieła jest okolicznością łagodzącą karę lub wręcz podstawą zakwalifikowania czynu jako społecznie szkodliwego w stopniu znikomym ${ }^{11}$. nie wniosły żadnego wkładu twórczego w powstanie dzieła, jako autorów lub współautorów danego utworu. Dotyczy to np. referatów, prac zaliczeniowych, współautorskich prac naukowych czy innych zbiorowych opracowań. Problem ten jest znamienny szczególnie dla środowiska naukowego, bowiem w niektórych dyscyplinach nauki zwyczajowo dopisuje się jako współautorów cały zespół naukowców pracujących nad danym zagadnieniem. W rezultacie, mimo że artykuł naukowy powstaje jedynie przy udziale np. dwóch osób, to jako współautorów wpisuje się także tych, którzy wykonywali inne prace związane $\mathrm{z}$ badaniami będącymi

\section{Z praktycznego punktu widzenia problematycznym} zagadnieniem jest zgoda twórcy na przypisanie sobie autorstwa lub współautorstwa utworu przez osobę, która nie uczestniczyła w stworzeniu utworu.

Jako plagiat traktowane jest także nieprawidłowe cytowanie, tj. $\mathrm{z}$ naruszeniem zasad dozwolonego cytatu określonych w art. 29 i 34 pr. aut. Częstym błędem pojawiającym się zwłaszcza w pracach popularnonaukowych jest nieumieszczanie przypisów w tekście, a jedynie spisu wykorzystanej literatury na końcu dzieła. Z kolei w pracach naukowych często cytowania oznaczane są zbyt rzadko, co przejawia się cytowaniem kolejno po sobie fragmentów cudzego utworu w oddzielnych akapitach i wskazaniem źródła jedynie przy ostatnim akapicie. Naruszeniem zasad prawidłowego cytowania jest także parafraza cudzego tekstu, która nie zostaje prawidłowo oznaczona ${ }^{12}$.

Z praktycznego punktu widzenia problematycznym zagadnieniem jest zgoda twórcy na przypisanie sobie autorstwa lub współautorstwa utworu przez osobę, która nie uczestniczyła w stworzeniu utworu. Dość powszechnym zjawiskiem jest dopisywanie osób, które

11 N. Daśko (w:) A. Michalak (red.), Ustawa o prawie..., s. 759.

12 Tamże; J. Zagrodnik (w:), P. Ślęzak, Ustawa o prawie..., art. 115 , nb. 8 , Legalis. przedmiotem artykułu, np. kierowali pracą zespołu, prowadzili badania laboratoryjne, zbierali dane, dokonywali korekty tekstu itp. ${ }^{13}$ Tego rodzaju praktyka jest nieuprawniona, ponieważ autorem danego utworu może być jedynie osoba, która wniosła wkład twórczy w rozumieniu prawa autorskiego $\mathrm{w}$ powstanie danego dzieła. Jednakże w doktrynie wskazuje się, że w przypadku osób, które wniosły znaczny wkład merytoryczny w powstanie utworu, np. pomysłodawców badań naukowych, czy osób wykonujących badania empiryczne itp. uwzględnienie ich autorstwa powinno być dopuszczalne $\mathrm{z}$ uwagi na uprawnienie wynikające $\mathrm{z}$ art. 23 k.c. ${ }^{14}$, określającego dobro osobiste w postaci własności intelektualnej, chronione niezależnie od innych przepisów ${ }^{15}$. Wydaje się jednak, że zamiast tworzenia niejasnych i trudnych do uzasadnienia wyjątków

13 N. Daśko (w:) A. Michalak (red.), Ustawa o prawie..., s. 761.

14 Ustawa z dnia 23 kwietnia 1964 r. Kodeks cywilny, t.j. Dz.U. 2019, poz. 1145 (dalej: k.c.).

15 K. Gienas (w:) E. Ferenc-Szydełko, Ustawa o prawie ...., art. 115, nb. 32, Legalis. 
- wszak pomysł naukowy czy przeprowadzenie badań nie są tożsame z wytworzeniem utworu, właściwszym rozwiązaniem jest po prostu stosowne i precyzyjne oznaczanie wkładu danej osoby w powstanie dzieła (np. wymienienie w artykule osób, które pracowały przy badaniach, i wskazanie w jakim zakresie).

Równie często osoby z większym dorobkiem naukowym z uwagi na swoją pozycję naukową (np. kierownik katedry, kierownik grantu, promotor) wymagają od młodszych współpracowników dopisywania ich jako współautorów do tworzonych przez nich prac, co określa się zjawiskiem „honorowego autorstwa”. Jednak również rzeczywiści autorzy, np. młodzi naukowcy, chętnie proponują takie rozwiązania bardziej utytułowanym naukowcom, aby w ten sposób "podnieść rangę" swoich prac, czy uzyskać możliwość publikacji w prestiżowym czasopiśmie lub wydawnictwie $^{16}$. W dobie wysoko rozwiniętego „systemu punktowego" panującego na uczelniach wyższych tego rodzaju działania podejmowane są często także w celu sztucznego pomnażania dorobku naukowego i zdobywania punktów przez autorów, którzy zawierają swoiste porozumienia polegające na dopisywaniu się jako współtwórcy do utworów stworzonych kolejno samodzielnie przez każdego $\mathrm{z}$ nich ${ }^{17}$.

Niezależnie od tego, czy rzeczywisty twórca wyraził zgodę na to, aby inne osoby przypisały sobie autorstwo lub współautorstwo stworzonego przez niego utworu, takie zachowanie wypełnia znamiona przestępstwa $\mathrm{z}$ art. 115 ust. 1 pr. aut. Wynika to $\mathrm{z}$ konstrukcji autorskich praw osobistych przyjętej w polskim prawie (podobnie jak w wielu innych państwach Europy), opierającej się na zasadzie nieprzenoszalności praw osobistych. W świetle tej zasady autor nie może przenieść prawa do autorstwa dzieła ani się go zrzec ${ }^{18}$. Wobec powyższego nie można mówić o kontratypie zgody uprawnionego, w tym wypadku autora, na naruszenie dobra osobistego, jakim jest autorstwo, a taką zgodę należy co do zasady traktować jako prawnie nieskuteczną ${ }^{19}$.

16 N. Daśko (w:) A. Michalak (red.), Ustawa o prawie..., s. 761.

17 J. Zagrodnik (w:) P. Ślęzak, Ustawa o prawie..., art. 115, nb. 9.

18 E. Wojnicka, B. Giesen (w:) System prawa prywatnego, t. 13, Warszawa 2017, s. 326.

19 Z. Ćwiąkalski (w:) J. Barta i in., Prawo autorskie i prawa pokrewne. Komentarz, Kraków [Zakamycze] 2005. s. 807;
Osobnym zagadnieniem jest ghostwirting, czyli pisanie utworów na zamówienie, przy jednoczesnej zgodzie na rozpowszechnianie ich pod cudzym nazwiskiem i z zachowaniem własnego autorstwa w tajemnicy. W zakres ghostwritingu wchodzi szereg różnych czynów, przy czym najbardziej powszechne to pisanie przemówień dla polityków, pisanie książek, np. autobiografii, poradników, przez dziennikarzy dla celebrytów, sportowców itp., ale też sporządzanie na zamówienie prac naukowych ${ }^{20}$. Karnoprawne oceny tych zjawisk nie są jednolite. Przyjmuje się, że dopuszczalne jest wyrażenie zgody przez autora na przywłaszczanie sobie jego autorstwa przez osobę, która nie brała udziału w procesie twórczym w przypadkach, gdy dotyczy to rynku komercyjnego, a także pisania przemówień dla polityków czy przełożonych itd. ${ }^{21}$ Natomiast tego rodzaju zgoda nie będzie skuteczna, jeżeli na podstawie określonego utworu sprawca miałby uzyskać np. awans, stopień lub tytuł zawodowy czy ocenę pracowniczą itd., ponieważ w ten sposób dochodziłoby do bezprawnego uzyskiwania określonych uprawnieńn ${ }^{22}$. Najbardziej powszechnym zjawiskiem w tym kontekście jest sprzedaż i kupowanie prac naukowych, w tym zwłaszcza prac dyplomowych (licencjackich, magisterskich, doktorskich), a także np. referatów i prac zaliczeniowych.

Osoba kupująca pracę zrealizuje znamiona czynu zabronionego $\mathrm{z}$ art. 115 ust. 1 pr. aut. w momencie, w którym w dowolny sposób uzewnętrzni przywłaszczenie sobie autorstwa, np. przedkładając pracę do sprawdzenia promotorowi, składając ją do dziekanatu, podpisując swoim nazwiskiem itd. Ponadto w przypadku prac dyplomowych obowiązkowo należy złożyć oświadczenie o samodzielnym przygotowaniu pracy, co w przypadku przedłożenia pracy będącej plagiatem skutkuje dodatkowo realizacją znamion czynu zabronionego określonego w art. 271 k.k. ${ }^{23}$

J. Raglewski (w:) D. Flisak (red.), Ustawa o prawie autorskim..., s. 1414-1415.

20 E. Wojnicka, B. Giesen (w:) System prawa prywatnego, s. $324-326$.

21 A. Szewc, Plagiat, „Monitor Prawniczy” 1996, nr 2, s. 44.

22 N. Daśko (w:) A. Michalak (red.), Ustawa o prawie..., s. 761

23 Ustawa z dnia 6 czerwca 1997 r. Kodeks karny, t.j. Dz.U. 2019, poz. 1950 (dalej: k.k.). 
(poświadczenie nieprawdy). Następnie, gdy praca stanowiąca plagiat zostanie obroniona i sprawca uzyska dyplom, wypełni także znamiona czynu zabronionego $\mathrm{z}$ art. 272 k.k., tj. wyłudzenie dokumentu poświadczającego nieprawdę, $\mathrm{w}$ tym wypadku będzie to dokument poświadczający uzyskanie tytułu zawodowego w obliczu niesamodzielnego sporządzenia pracy dyplomowej ${ }^{24}$. Z kolei zachowanie polegające na pisaniu prac na zamówienie, najczęściej w celu osiągnięcia korzyści majątkowej, należy rozpatrywać w kategoriach pomocnictwa lub podżegania do czynu zabronionego $\mathrm{z}$ art. 115 ust. 1 pr. aut. ${ }^{25}$.

Naruszenie prawa do autorstwa przez nauczycieli akademickich, studentów i doktorantów może skutkować odpowiedzialnością dyscyplinarną, uregulowaną $\mathrm{w}$ ustawie prawo o szkolnictwie wyższym ${ }^{26}$. Dodatkowo, zgodnie z art. 77 ust. 5 pr. szkol. wyż., w przypadku, gdy w pracy dyplomowej stanowiącej podstawę nadania tytułu zawodowego osoba ubiegająca się o ten tytuł przypisała sobie autorstwo istotnego fragmentu lub innych elementów cudzego utworu lub ustalenia naukowego, rektor w drodze decyzji administracyjnej stwierdza nieważność dyplomu. Analogiczna regulacja obejmuje także prace doktorskie (art. 195 pr. szkol. wyż.). Istnieje również możliwość wznowienia postępowania administracyjnego w sprawie nadania stopnia lub tytułu naukowego w przypadku pracy naukowej będącej plagiatem na podstawie art. 145 $\$ 1$ pkt 2 (przestępstwo), art. $145 \$ 1$ pkt 1 (fałszywy dowód) lub art. $145 \$ 1$ pkt 5 k.p.a. ${ }^{27}$ (nowy, istotny dla sprawy i nieznany organowi dowód przed wydaniem decyzji) $)^{28}$.

Druga czynność sprawcza kryminalizowana na gruncie art. 115 ust. 1 pr. aut. polega na wprowadze-

24 Wyrok SR Szczecin-Centrum w Szczecinie z 22 grudnia 2016 r., IV K 912/14, LEX nr 2410111; J. Błachut, Prawne konsekwencje tworzenia prac dyplomowych na zlecenie, „Państwo i Prawo” 2005, nr 5, s. 155.

25 N. Daśko (w:) A. Michalak (red.), Ustawa o prawie..., s. 762,

26 Ustawa z dnia 20 lipca 2018 r. Prawo o szkolnictwie wyższym i nauce, t.j. Dz.U. 2020, poz. 85 (dalej: pr. szkol. wyż.).

27 Ustawa z dnia 14 czerwca 1960 r. Kodeks postępowania administracyjnego, t.j. Dz.U. 2020, poz. 256 (dalej: k.p.a.).

28 N. Daśko (w:) A. Michalak (red.), Ustawa o prawie..., s. 764765; wyrok WSA w Warszawie z 8 kwietnia 2009 r., I SA/ Wa 986/08, Legalis nr 208954 niu w błąd co do autorstwa całości lub części cudzego utworu albo artystycznego wykonania. Przez wprowadzenie w błąd co do autorstwa należy rozumieć inne zachowania niż przywłaszczenie autorstwa, ponieważ każde przywłaszczenie autorstwa jednocześnie jest wprowadzeniem w błąd co do autorstwa. Różnica między tymi zachowaniami sprowadza się więc do tego, że w przypadku plagiatu sprawca przypisuje sobie to autorstwo (wykonawstwo), zaś w przypadku wprowadzenia w błąd co do autorstwa sprawca wskazuje inną osobę niż on jako rzekomego autora utworu (artystycznego wykonania) ${ }^{29}$. Wprowadzenie w błąd co do autorstwa może zostać dokonane w dowolny sposób, przez dowolne czynności, na skutek których sprawca wywołuje błędne przekonanie co do autorstwa określonego utworu (artystycznego wykonania) u osób trzecich. Będzie to np. podpisanie zdjęcia nazwiskiem osoby, która nie jest jego autorem, ale też np. tolerowanie błędnej informacji o autorstwie (wykonawstwie), bowiem znamiona przestępstwa wprowadzenia w błąd co do autorstwa może wypełnić nie tylko sprawca, który dokonał "pierwotnego" wprowadzenia w błąd, ale także każda kolejna osoba, która będąc zobowiązana do sprostowania błędnej informacji, świadomie błąd ten utrwala, np. promotor, który zauważa błąd co do autorstwa w pracy studenta i nie poprawia go ${ }^{30}$.

Nie wypełnia znamion przestępstwa $\mathrm{z}$ art. 115 ust. 1 pr. aut. zachowanie polegające na przywoływaniu fikcyjnych utworów (artystycznych wykonań), gdyż nie jest możliwe wprowadzenie w błąd co do autorstwa w sytuacji, gdy takie dzieło w ogóle nie istnieje ${ }^{31}$. W przypadku działalności naukowej takie zachowanie traktować można jako nierzetelność naukową, skutkującą odpowiedzialnością dyscyplinarną. Natomiast działanie polegające na przywoływaniu istniejącego utworu (artystycznego wykonania) ze wskazywaniem

29 N. Daśko (w:) A. Michalak (red.), Ustawa o prawie..., s. 763; K. Gienas (w:) E. Ferenec-Szydełko, Ustawa o prawie..., art. 115, nb. 4 .

30 Z. Ćwiąkalski (w:) J. Barta, R. Markiewicz, Ustawa o prawie..., s. 809; M. Mozgawa (w:) System prawa karnego, t. 11, Warszawa 2014, $₫ 74$, nb. 96.

31 K. Gienas (w:) E. Ferenec-Szydełko, Ustawa o prawie..., art. 115, nb. 18 . 
jako jego twórcy osoby fikcyjnej realizuje znamiona art. 115 ust. 1 pr. aut. ${ }^{32}$

W przypadku obu czynności sprawczych kryminalizowanych na gruncie art. 115 ust. 1 pr. aut. nie ma znaczenia, czy twórca, którego autorstwo jest przywłaszczane albo co do autorstwa którego następuje wprowadzenie w błąd, żyje, czy nie. Autorskie prawa osobiste są bowiem nieograniczone w czasie ${ }^{33}$.

Czyny zabronione stypizowane w art. 115 ust. 1 pr. aut. mają charakter powszechny, ich sprawcą może być każdy, zaś ich strona podmiotowa charakteryzuje się umyślnością. W przypadku czynności sprawczej polegającej na przywłaszczeniu sobie cudzego autor-
Szczególnym zagadnieniem w kontekście problematyki przywłaszczenia autorstwa jest zjawisko autoplagiatu, polegające na powtórnym przedstawieniu przez twórcę tego samego utworu lub jego fragmentów jako nowych. Jednak wbrew swej nazwie nie ma ono nic wspólnego z plagiatem, jednakże jest dość często pojawiającą się, zwłaszcza w środowisku akademickim, „patologią". Wskazane zachowanie nie wypełnia znamion art. 115 ust. 1 pr. aut., ponieważ nie dochodzi tutaj do przywłaszczenia cudzego autorstwa, skoro zachowanie sprawcy skierowane jest na jego własny utwór. W niektórych jednak przypadkach tego rodzaju zachowanie może skutkować odpo-

\section{W Polsce za plagiat i wprowadzenie w błąd co do autorstwa skazywani są najczęściej studenci składający prace dyplomowe.}

stwa w grę wchodzi jedynie zamiar bezpośredni (dolus directus), natomiast druga czynność sprawcza - wprowadzenie w błąd co do autorstwa - może być podjęta zarówno z zamiarem bezpośrednim, jak i ewentualnym (dolus eventualis). Czyny zabronione stypizowane w art. 115 ust. 1 pr. aut. zagrożone są sankcją alternatywnie oznaczoną, składającą się z grzywny, kary ograniczenia wolności oraz kary pozbawienia wolności do lat trzech. Ściganie następuje z oskarżenia publicznego $z$ urzędu. Wydaje się to rozwiązaniem zasadnym, gdyż w przypadku innego trybu ścigania w wielu przypadkach pokrzywdzeni tymi czynami zabronionymi, zwłaszcza przywłaszczeniem autorstwa, nie byliby zainteresowani ich ściganiem w sytuacjach, gdy przestępstwo popełniono za ich zgodą, chodzi tu np. o pisanie prac naukowych na zlecenie, dopisywanie kolegów jako współautorów itd. Zwalczanie tego rodzaju zachowań nie byłoby więc możliwe ${ }^{34}$.

32 N. Daśko (w:) A. Michalak (red.), Ustawa o prawie..., s. 763-764.

33 Tamże.

34 Tamże, s. 770-773. wiedzialnością dyscyplinarną; chodzi tu zwłaszcza o sztuczne pomnażanie dorobku naukowego przez nauczycieli akademickich, doktorantów lub studentów. Ponadto powtórne przedstawianie określonych utworów jako nowych może prowadzić do wypełnienia znamion oszustwa $z$ art. $286 \$ 1$ k.k., np. w relacji twórca-wydawca lub producent czy w przypadku rozliczania projektów badawczych ${ }^{35}$.

\section{Analiza danych statystycznych}

dotyczących art. 115 ust. 1 ustawy o prawie autorskim i prawach pokrewnych

Podstawą badań statystycznych były dane uzyskane w Ministerstwie Sprawiedliwości, obejmujące m.in. liczbę skazań, płeć i wiek sprawców, miejsce popełnienia przestępstwa, a także wymiar kar i środków karnych oraz przepadku i środków kompensacyjnych. Dane te dotyczyły wspomnianego okresu między rokiem 2013 a 2017 i obejmowały cały kraj.

$\mathrm{W}$ analizowanym okresie odnotowano jedynie 84 prawomocne skazania $\mathrm{z}$ art. 115 ust. 1 pr. aut. (zob.

35 Tamże, s. 770 
Wykres 1. Liczba osób prawomocnie skazanych z art. 115 ustawy o prawie autorskim w latach 2013-2017

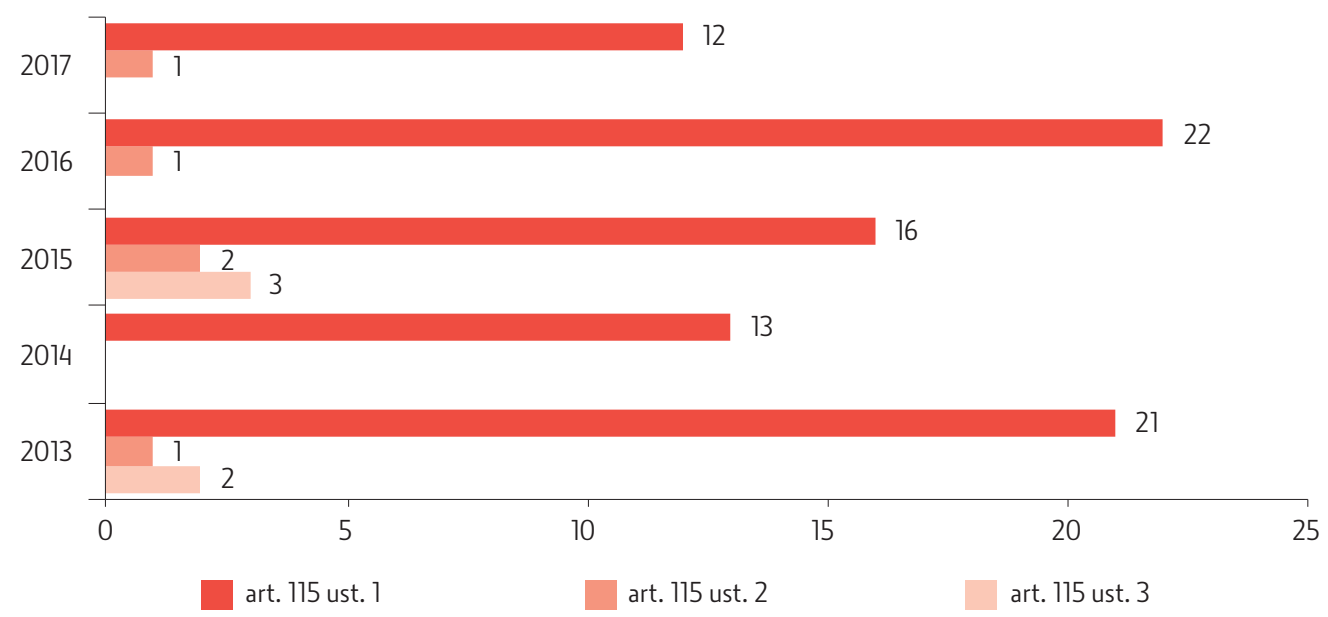

Źródło: Opracowanie własne na podstawie danych Ministerstwa Sprawiedliwości.

wykres 1), przy czym, aby umieścić tę liczbę w odpowiednim kontekście, wskazać należy, że ogólna liczba osób dorosłych prawomocnie skazanych za przestępstwa w Polsce w latach 2013-2017 wyniosła 1439543.

Dla porównania liczba skazań z przepisu art. 116 pr. aut., penalizującego piractwo, jest sześć razy większa niż w przypadku art. 115 ust. 1 pr. aut., co czyni piractwo najczęściej popełnianym przestępstwem przeciwko prawom autorskim i prawom pokrewnym, a przynajmniej najczęściej wykrywanym.

Natomiast, przyglądając się liczbie skazań z poszczególnych ustępów art. 115 pr. aut., można zauważyć, że niemal wszystkie skazania (90\%) dotyczą przestępstwa przywłaszczenia autorstwa i wprowadzenia w błąd co do autorstwa (art. 115 ust. 1 pr. aut.), pozostałe typy czynów zabronionych, określone w art. 115 ust. 2 i 3 pr. aut., pojawiają się bardzo rzadko, a w niektórych latach nawet wcale (zob. wykres 1).

Interesujących informacji dostarczają dane dotyczące wieku sprawców (zob. wykres 2 i 3). Okazuje się, że ponad połowa (57\%) sprawców skazanych z art. 115 ust. 1 pr. aut. to osoby bardzo młode, w wieku 22-29 lat. Zestawienie tych danych z wynikami badań aktowych (zob. pkt 3) prowadzi do wniosku, że w Polsce za plagiat i wprowadzenie w błąd co do autorstwa skazywani są najczęściej studenci składający prace dyplomowe. Wyższa wykrywalność tych przestępstw w przypadku tej grupy osób wynika zapewne z obowiązku stosowania na uczelniach wyższych systemów antyplagiatowych do sprawdzania prac dyplomowych (art. 76 ust. 1 pkt 3 [4] pr. szkol. wyż.), a także z nałożonego na instytucje państwowe obowiązku zawiadamiania organów ścigania o przestępstwie ściganym z urzędu (art. 304 k.p.k. ${ }^{36}$ ).

Analizując płeć sprawców skazanych z art. 115 ust. 1 pr. aut., można zaobserwować nietypowe zjawisko (zob. wykres 4). Otóż w badanym okresie większość (56\%) skazanych z tego przepisu stanowiły kobiety, a nie mężczyźni, jak można by przypuszczać na podstawie ogólnej wiedzy kryminologicznej odnośnie udziału kobiet w populacji osób skazanych, wskazującej, że liczba skazanych mężczyzn jest kilkakrotnie większa od liczby skazanych kobiet. Zdaje się, że ten nietypowy trend w przypadku przestępstwa plagiatu można wytłumaczyć w ten sposób, że skoro większość spraw $z$ art. 115 ust. 1 pr. aut. dotyczy studentów, to biorąc pod uwagę, że na polskich uczelniach wyższych

36 Ustawa z dnia 6 czerwca 1997 r. Kodeks postępowania karnego, t.j. Dz.U. 2020, poz. 30 (dalej: k.p.k.). 
Wykres 2. Prawomocnie skazani z art. 115 ust. 1 ustawy o prawie autorskim w latach 2013-2017 według wieku

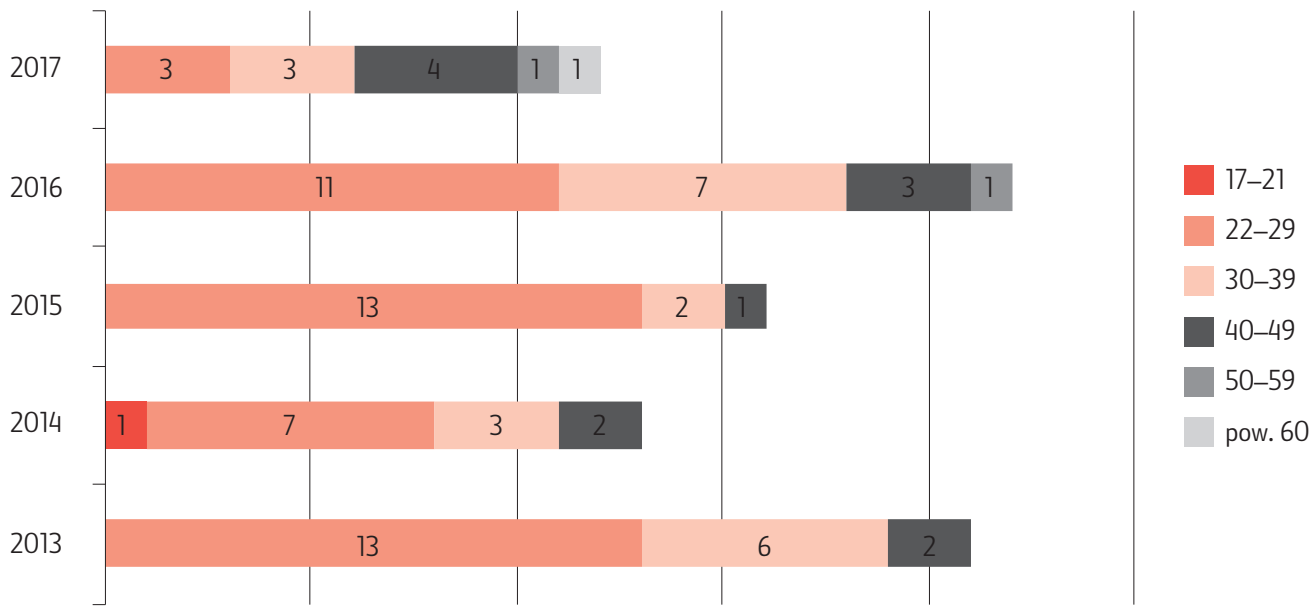

Źródło: jak pod wykresem 1.

Wykres 3. Prawomocnie skazani z art. 115 ust. 1 ustawy o prawie autorskim w latach 2013-2017 według wieku w procentach

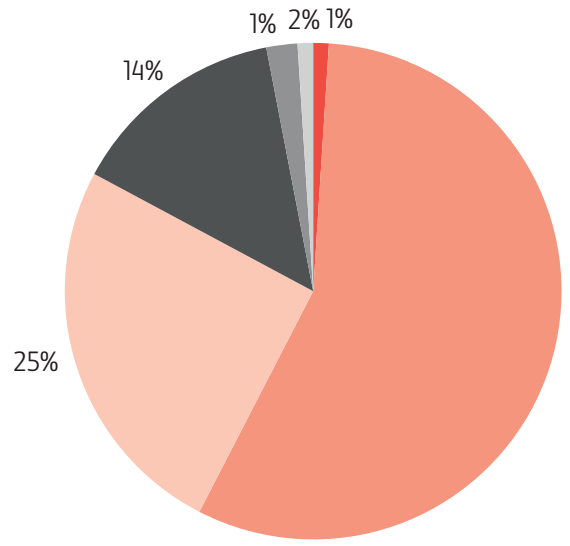

$57 \%$
Wykres 4. Prawomocnie skazani z art. 115 ust. 1 ustawy o prawie autorskim w latach 2013-2017 według płci

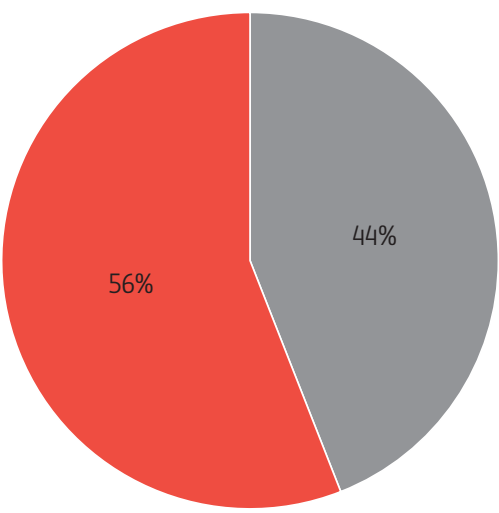

mężczyźni kobiety

Źródło: jak pod wykresem 1.

Źródło: jak pod wykresem 1. 
Wykres 5. Prawomocnie skazani z art. 115 ust. 1 ustawy o prawie autorskim w latach 2013-2017 według miejsca popełnienia przestępstwa (województwa)

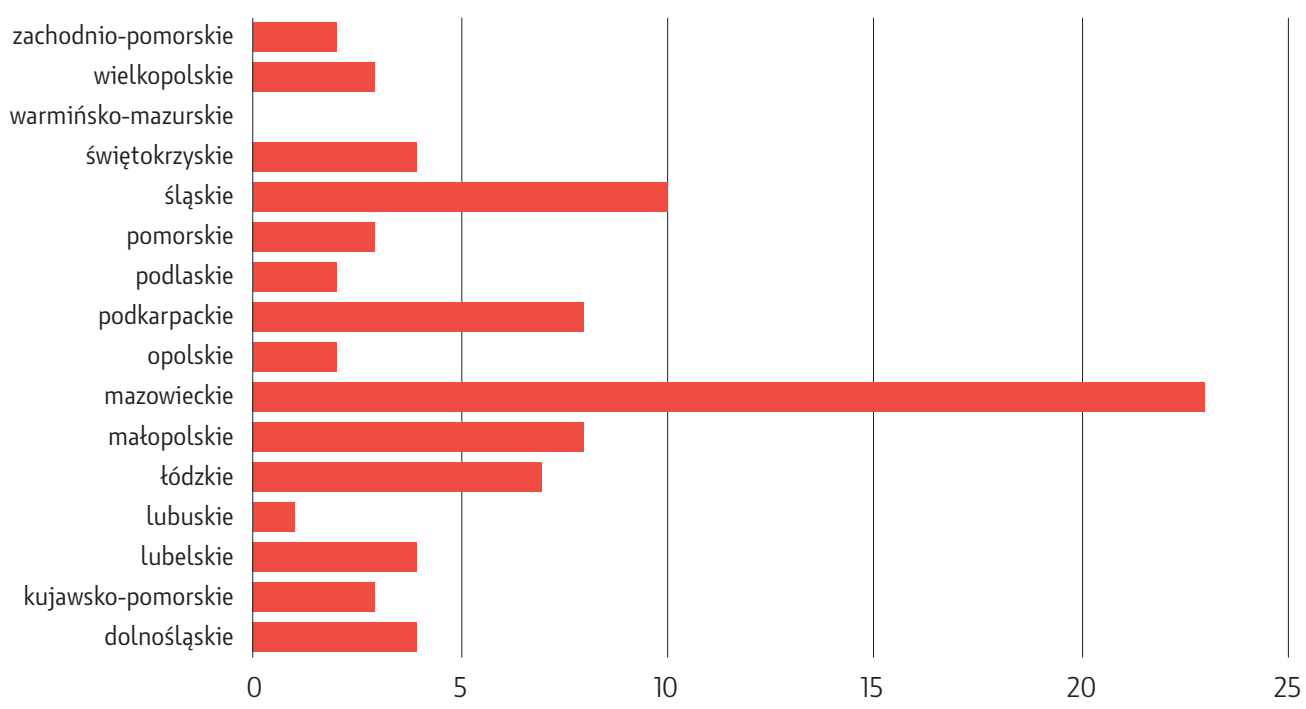

Źródło: jak pod wykresem 1.

Wykres 6. Prawomocnie skazani z art. 115 ust. 1 ustawy o prawie autorskim w latach 2013-2017 według wymiaru kary

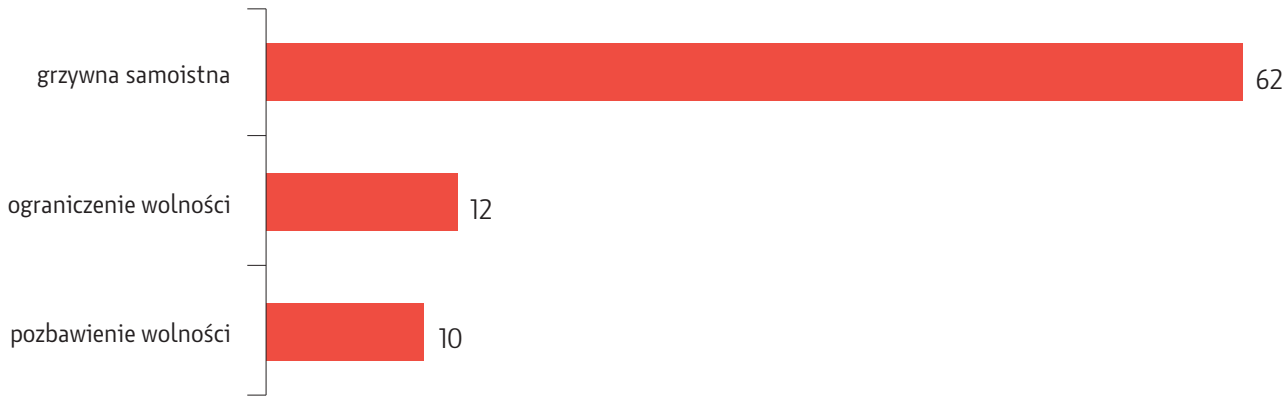

Źródło: jak pod wykresem 1.

studiuje więcej studentek niż studentów, studentki muszą statystycznie częściej popełniać to przestępstwo. Jeżeli chodzi o miejsce popełnienia przestępstwa, to jedyne dostępne dane dotyczyły podziału na województwa (zob. wykres 5). Ich analiza pokazuje, że najwięcej przestępstw popełniono w województwie mazo- wieckim (27\%), kolejno zaś w śląskim, małopolskim i podkarpackim. Jedynie w województwie warmińsko-mazurskim $w$ analizowanym okresie nie popełniono ani jednego przestępstwa $z$ art. 115 ust. 1 pr. aut.

Kolejnym ważnym aspektem badania danych statystycznych były sankcje karne (zob. wykres 6). Jak 
Tabela 1. Liczba przebadanych spraw w ramach badań aktowych

\begin{tabular}{|l|c|}
\hline \multicolumn{1}{|c|}{ Nazwa sądu } & Liczba przebadanych spraw \\
\hline Sąd Rejonowy Gdańsk-Południe w Gdańsku & 4 \\
\hline Sąd Rejonowy Katowice-Wschód w Katowicach & 7 \\
\hline Sąd Rejonowy dla Krakowa-Śródmieścia w Krakowie & 2 \\
\hline Sąd Rejonowy Lublin-Zachód w Lublinie & 4 \\
\hline Sąd Rejonowy dla Łodzi-Śródmieścia w Łodzi & 5 \\
\hline Sąd Rejonowy Poznań-Stare Miasto w Poznaniu & 3 \\
\hline Sąd Rejonowy Szczecin-Centrum w Szczecinie & 3 \\
\hline Sąd Rejonowy dla Warszawy-Śródmieścia w Warszawie & 9 \\
\hline Sąd Rejonowy dla Warszawy Pragi-Południe w Warszawie & 3 \\
\hline Sąd Rejonowy dla Wrocławia-Śródmieścia we Wrocławiu & 3 \\
\hline
\end{tabular}

wynika z analizy w latach 2013-2017, największy odsetek spośród kar orzeczonych za przestępstwa z art. 115 ust. 1 pr. aut. stanowiła kara grzywny (74\%). W badanym okresie zapadło także 12 kar ograniczenia wolności i 10 kar pozbawienia wolności (wszystkie $\mathrm{z}$ warunkowym zawieszeniem wykonania).

$\mathrm{W}$ sprawach $\mathrm{z}$ art. 115 ust. 1 pr. aut. sądy rzadko kiedy orzekają środki karne, przepadek lub środki kompensacyjne. Jedynie w kilku sprawach pojawił się przepadek przedmiotów i obowiązek naprawienia szkody.

\section{Badania aktowe dotyczace spraw}

\section{$z$ art. 115 ust. 1 ustawy o prawie autorskim} i prawach pokrewnych

W celu poznania okoliczności faktycznych spraw plagiatowych, a także sprawdzenia, jak sądy sobie radzą z kwalifikacją prawną naruszeń praw autorskich, przeprowadzono badania aktowe dotyczące spraw z lat 2013-2017, które zakończyły się prawomocnym wyrokiem skazującym. Do badania wybrano 10 spośród 14 sądów rejonowych wyznaczonych przez Ministra Sprawiedliwości na podstawie art. 123 pr. aut. do rozpoznawania spraw o przestępstwa, o których mowa w art. 115-119 pr. aut., na obszarze właściwości danego sądu okręgowego. W sumie przebadano 45 spraw (zob. tabela 1).
Zdecydowana większość spraw (78\%) z art. 115 ust. 1 pr. aut. dotyczyła plagiatu, który można określić „uczelnianym”, przy czym najwięcej przypadków to przywłaszczenie autorstwa w pracy dyplomowej. Najczęściej były to prace licencjackie, następnie podyplomowe, magisterskie, a wyjątkowo doktorskie czy habilitacyjne. Jeżeli chodzi o dyscypliny naukowe, których dotyczyły przywłaszczane, podyplomowe, prace, to wskazać należy, że dominowały nauki humanistyczne. Sprawcami w większości przypadków byli studenci, rzadziej doktoranci czy pracownicy naukowi składający pracę w ramach odpowiedniej procedury. Kilka spraw dotyczyło osób piszących prace dyplomowe na zlecenie, występujących w roli sprawców pomocniczych do przestępstwa przywłaszczania autorstwa. Jedna z nich prowadziła stronę internetową, na której oficjalnie reklamowała swoje usługi i za pośrednictwem której klienci składali zamówienia. Sprawca oferował prace z dowolnej dziedziny nauki, a w przypadku bardziej skomplikowanej tematyki zlecał wykonanie zadania podwykonawcom, sam zajmując się jedynie koordynacją zamówienia. Drugi rodzaj sprawców pomocniczych, którzy pojawili się w badanych sprawach, to osoby, które pomagały nawiązać kontakt pomiędzy osobą zainteresowaną kupieniem gotowej pracy a osobą piszącą pracę na zlecenie. 
W przypadkach, gdy praca stanowiąca plagiat została obroniona i sprawca uzyskał dyplom, zarzut uzupełniany był o czyn z art. 272 k.k., tj. wyłudzenie dokumentu poświadczającego nieprawdę. W tych wypadkach traktowano w ten sposób dokument poświadczający uzyskanie tytułu zawodowego w obliczu niesamodzielnego sporządzenia pracy dyplomowej.

$\mathrm{W}$ ramach tej grupy spraw odnotowano także pojedyncze przypadki dotyczące przywłaszczenia autorstwa artykułu naukowego i opublikowania go w czasopiśmie naukowym.

Druga grupa spraw, zdecydowanie mniejsza, dotyczyła plagiatu popełnianego „w ramach działalności gospodarczej”. Najczęściej chodziło o przywłaszczenia przez przedsiębiorców autorstwa logo, zdjęć, plakatów, grafik, ale także np. skryptów dotyczących obsługi programów, schematów zarządzania spółką (tutaj zarzut uzupełniony był dodatkowo o czyn $\mathrm{z}$ art. 23 ust. 2 ustawy o zwalczaniu nieuczciwej konkurencji ${ }^{37}$ ) itd.

Jak pokazują badania, w praktyce pojawiają się problemy z kwalifikacją prawną naruszeń praw autorskich. I tak w przypadku przywłaszczenia autorstwa i nieuprawnionego rozpowszechniania utworu zawierającego plagiat sądy często stosują art. 115 ust. $1 \mathrm{w}$ zb. $\mathrm{z}$ art. 115 ust. 2 pr. aut., co jest zabiegiem niepoprawnym. Penalizowana na gruncie art. 115 ust. 2 pr. aut. czynność sprawcza w postaci rozpowszechniania bez podania nazwiska lub pseudonimu twórcy cudzego utworu w postaci oryginalnej lub w postaci opracowania nie obejmuje sytuacji, w których sprawca przywłaszcza sobie autorstwo, takie zachowanie jest bowiem kryminalizowane na gruncie art. 115 ust. 1 pr. aut. W przypadku art. 115 ust. 2 pr. aut. chodzi o nieposzanowanie cudzego autorstwa, poprzez rozpowszechnianie cudzych dzieł anonimowo, ale bez przypisywania tego autorstwa sobie.

W sytuacji, gdy przy przejęciu całości cudzego utworu i przywłaszczeniu autorstwa dochodzi jednocześnie do naruszenia praw wyłącznych poprzez jego nieuprawnione rozpowszechnianie w kwalifikacji prawnej powinno uwzględniać się art. 116 pr. aut. Naruszenia praw osobistych (w tym zwłaszcza prawa

37 Ustawa z dnia 16 kwietnia 1993 r. o zwalczaniu nieuczciwej konkurencji, t.j. Dz.U. 2019, poz. 1010. do autorstwa) i praw majątkowych krzyżują się i można wskazać trzy możliwe warianty: niektóre plagiaty nie naruszają praw wyłącznych do dzieła, np. kiedy autorskie prawa majątkowe wygasły - wówczas w kalifikacji prawnej czynu powinien pojawić się jedynie art. 115 pr. aut., $w$ innych przypadkach naruszenie majątkowych praw autorskich nie łączy się w ogóle z plagiatem, np. przy pirackim rozpowszechnianiu filmów, muzyki itd. i takie zachowanie kryminalizowane jest na gruncie art. 116 pr. aut., natomiast w trzecim wariancie naruszeń, pomijanym często przez sądy, pojawiają się przypadki polegające na równoczesnym naruszeniu praw osobistych, tj. na przywłaszczeniu sobie autorstwa utworu i praw majątkowych, które powinny skutkować kwalifikacją prawną z art. 115 ust. 1 pr. aut. w zb. z art. 116 (ust. 1, 2, 3 lub 4) pr. aut. ${ }^{38}$.

Zwraca uwagę również fakt, że sądy nie do końca rozróżniają czynności sprawcze stypizowane w art. 115 ust. 1 pr. aut. W opisie czynu często pojawiało się następujące sformułowanie: „przywłaszczył autorstwo, czym wprowadził w błąd co do autorstwa" np. władze uczelni. Tymczasem konstrukcja przepisu art. 115 ust. 1 pr. aut. prowadzi do konkluzji, że przez wprowadzenie w błąd należy rozumieć inne działania niż przywłaszczenie autorstwa, które $\mathrm{z}$ istoty swej zakłada wprowadzenie w błąd osób trzecich. Jak wskazywano wcześniej, w przypadku przywłaszczenia autorstwa sprawca przypisuje sobie to autorstwo, zaś w przypadku wprowadzenia w błąd co do autorstwa sprawca wskazuje inną osobę niż on jako rzekomego autora utworu (artystycznego wykonania).

Mimo że głównym przedmiotem badań były sprawy z art. 115 ust. 1 pr. aut. na marginesie można zauważyć, że sądy nie rozpoznają prawidłowo znamion art. 115 ust. 3 pr. aut. i art. 116 pr. aut. i często zachowania wypełniające dyspozycję tego ostatniego przepisu błędnie kwalifikują z art. 115 ust. 3 pr. aut. Nie ulega wątpliwości, że konstrukcja przepisu art. 115 ust. 3 pr. aut., wyrażająca się w ogólnikowym zwrocie: „w inny sposób niż określony w ust. 1 lub 2 narusza cudze prawo autorskie lub pokrewne", jest zbyt nieokreślona i nieostra, bowiem $\mathrm{w}$ istocie nie zawiera opisu zachowania stanowiącego podstawę odpowiedzialności karnej i nie pozwala stwierdzić, jakie konkretnie

38 R. Markiewicz, Zabawy z..., s. 88-89. 
zachowania są kryminalizowane. Użycie klauzuli „W inny sposób niż określony w ust. 1 lub ust. 2" jest jedynie dookreśleniem typu czynu zabronionego od strony negatywnej, z jego zakresu wyłączono bowiem określone we wcześniejszych ustępach przywłaszczenie autorstwa, wprowadzenie w błąd co do autorstwa całości lub części cudzego utworu albo artystycznego wykonania, rozpowszechnienie bez podania nazwiska lub pseudonimu twórcy cudzego utworu w wersji oryginalnej albo w postaci opracowania, artystycznego wykonania albo publiczne zniekształcenie takiego utworu, artystycznego wykonania, fonogramu, wideogramu lub nadania. Jednak mając na uwadze dalsze aut.). Z kolei wyniki przeprowadzonych badań aktowych pokazują, że zdecydowana większość spraw z art. 115 ust. 1 pr. aut. dotyczy pierwszej z kryminalizowanych na gruncie tego przepisu czynności sprawczej, tj. przywłaszczenia autorstwa. Pozostałe typy czynów zabronionych, określone w art. 115 ust. 2 i 3 pr. aut., albo w ogóle nie pojawiają się w praktyce wymiaru sprawiedliwości, albo pojawiają się jedynie pojedynczo - odnotowano raptem 10 prawomocnych skazań na przestrzeni 5 analizowanych lat, przy czym przynajmniej w 3 sprawach przyjęto błędną kwalifikację i art. 115 ust. 3 pr. aut. nie powinien mieć do nich zastosowania.

\section{Sądy karne nie rozpoznają prawidłowo znamion} czynów zabronionych stypizowanych w ustawie o prawie autorskim i prawach pokrewnych.

przepisy karne ustawy o prawie autorskim określające prawnokarną ochronę praw majątkowych i reguły kolizyjne pozwalające wyłączyć wielość ocen, trzeba zauważyć, że art. 115 ust. 3 pr. aut. będzie miał zastosowanie tylko w tych przypadkach naruszenia praw majątkowych, które nie są objęte dyspozycją innych przepisów ${ }^{39}$. Tymczasem w badanych sprawach sądy stosowały go często w przypadku nieuprawnionego rozpowszechniania cudzych utworów, podczas gdy tego rodzaju zachowania kryminalizowane są na gruncie art. 116 pr. aut.

\section{Uwagi końcowe}

Analiza liczby prawomocnych skazań z poszczególnych ustępów art. 115 pr. aut. prowadzi do wniosku, że w praktyce niemal wszystkie skazania (90\%) dotyczą przestępstwa przywłaszczenia autorstwa i wprowadzenia w błąd co do autorstwa (art. 115 ust. 1 pr.

39 N. Daśko (w:) A. Michalak (red.), Ustawa o prawie..., s. 768 769; Z. Ćwiąkalski (w:) J. Barta, R. Markiewicz, Ustawa o prawie..., s. 822-823; J. Zagrodnik (w:) P. Ślęzak, Ustawa o prawie..., art. 115, nb. 29.
Przyczyny tego zjawiska mogą być przynajmniej trzy: pokrzywdzeni czynami stypizowanymi w art. 115 ust. 2 i 3 pr. aut. wybierają drogę postępowania cywilnego do dochodzenia swoich roszczeń; istnieje duża ciemna liczba tych przestępstw, ponieważ organy ścigania ich nie wykrywają, np. z uwagi na niechęć ścigania przestępstw o niewielkim ciężarze gatunkowym, czy trudność w rozpoznaniu nieprecyzyjnych znamion czynu zabronionego z art. 115 ust. 3 pr. aut.; tego rodzaju przestępstwa prawie w ogóle nie są popełniane. Pierwszy i trzeci ze wskazanych możliwych powodów niewielkiej liczby skazań z art. 115 ust. 2 i 3 pr. aut. powinien skłonić ustawodawcę do przemyślenia decyzji o dekryminalizacji tych czynów, wydaje się bowiem, mając zwłaszcza na uwadze subsydiarność prawa karnego i fakt, że naruszeń praw autorskich w tym zakresie można dochodzić na drodze cywilnej, że utrzymywanie tych przepisów nie jest dostatecznie uzasadnione. $\mathrm{Z}$ kolei drugi ze wskazanych możliwych powodów niewielkiej liczby skazań powinien skutkować nowelizacją art. 115 ust. 3 pr. aut., mającą na celu precyzyjne dookreślenie znamion czynu zabronionego. 
Wyniki badań nie wskazują natomiast, że karnoprawna ochrona prawa do autorstwa (wykonawstwa) jest zbyteczna i należałoby zdekryminalizować czyn zabroniony określony w art. 115 ust. 1 pr. aut., poprzestając jedynie na cywilnoprawnych środkach ochrony. Wręcz przeciwnie, jak pokazują przeprowadzone badania aktowe, zdecydowana większość spraw $\mathrm{z}$ art. 115 ust. 1 pr. aut. dotyczy plagiatu określonego jako „uczelniany”, w którego przypadku jedynie reżim odpowiedzialności karnej jest w stanie zagwarantować zwalczanie takich patologii jak honorowe autorstwo czy pisanie prac na zamówienie.

W praktyce dużym problemem okazuje się kwalifikacja naruszeń praw autorskich i praw pokrewnych. Niestety sądy karne nie rozpoznają prawidłowo znamion czynów zabronionych stypizowanych w ustawie o prawie autorskim i prawach pokrewnych. Wynika to prawdopodobnie z tego, że bez znajomości aspektów cywilnoprawnych prawa własności intelektualnej, składającego się nie tylko z prawa autorskiego i praw pokrewnych, ale także z prawa własności przemysłowej i zwalczania nieuczciwej konkurencji, niemożliwe jest właściwe kwalifikowanie naruszeń w obrębie wskazanych praw. Nie bez powodu ustawodawca zdecydował się znowelizować postępowanie cywilne i wprowadzić „sądy specjalne” dla spraw własności intelektualnej, w których orzekać mają wyspecjalizowani sędziowie, eksperci znający specyfikę tej dziedziny prawa ${ }^{40}$. Należy postulować, by analogiczne rozwiązanie pojawiło się w Kodeksie postępowania karnego.

\section{Bibliografia}

Barta J., Markiewicz R., Prawo autorskie, Warszawa [Wolters Kluwer] 2017.

Błachut J., Prawne konsekwencje tworzenia prac dyplomowych na zlecenie, „Państwo i Prawo” 2005, nr 5, s. 153-162.

Ćwiąkalski Z. (w:) J. Barta i in., Prawo autorskie i prawa pokrewne. Komentarz, Kraków [Zakamycze] 2005.

Daśko N. (w:) A. Michalak (red.), Ustawa o prawie autorskim i prawach pokrewnych. Komentarz, Warszawa [C.H. Beck] 2019.

Gienas K. (w:) E. Ferenc-Szydełko, Ustawa o prawie autorskim i prawach pokrewnych. Komentarz, Warszawa [C.H. Beck] 2016.

Markiewicz R., Zabawy z prawem autorskim, Warszawa [Wolters Kluwer] 2015.

Mozgawa M. (w:) System prawa karnego, t. 11, Warszawa [C.H. Beck] 2014.

Raglewski J. (w:) D. Flisak (red.), Ustawa o prawie autorskim i prawach pokrewnych. Komentarz, Warszawa [C.H. Beck] 2014.

Szewc A., Plagiat, „Monitor Prawniczy” 1996, nr 2, s. 43-46.

Wojnicka E., Giesen B. (w:) System prawa prywatnego, t. 13, Warszawa [C.H. Beck] 2017.

Zagrodnik J. (w:) P. Ślęzak, Ustawa o prawie autorskim i prawach pokrewnych. Komentarz, Warszawa [C.H. Beck] 2017.

40 Ustawa z dnia 13 lutego 2020 r. o zmianie ustawy - Kodeks postępowania cywilnego oraz niektórych innych ustaw, Dz.U. 2020, poz. 288. 